\title{
The Effect of Maternal Ketanserin Treatment on Foetal 5-HT Receptor Function in Umbilical Cord Artery of Pre-Eclamptic Patients
}

\author{
L.M. Hanffa ${ }^{a}$ S. Gupta ${ }^{b} \quad$ A. MaassenVanDenBrink ${ }^{b} \quad$ E.A.P. Steegers ${ }^{c}$ P.R. Saxena ${ }^{b}$ \\ A.G. Vulto ${ }^{a}$ W. Visser ${ }^{c}$

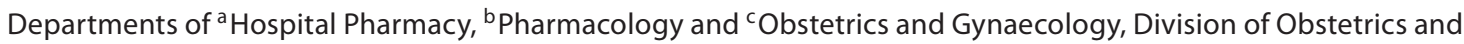 \\ Prenatal Medicine, Erasmus University Medical Centre, Rotterdam, The Netherlands
}

\section{Key Words}

5-HT · Serotonin receptor $\cdot$ Ketanserin • Umbilical cord •

Pre-eclampsia $\cdot$ Foetus

\begin{abstract}
Background: Maternal treatment with the $5-\mathrm{HT}_{2 \mathrm{~A}}$ receptor antagonist ketanserin (KT) in pre-eclamptic patients is associated with a high placental transmission of $\mathrm{KT}$, resulting in pharmacologically active levels of KT in the umbilical cord artery (UCA) and the neonate. Prolonged exposure to a $5-\mathrm{HT}$ receptor antagonist may influence the functionality of foetal 5-HT receptors and compromise foetal development. $\mathbf{O b}$ jective: To study whether exposure to KT influences the characteristics of foetal 5-HT receptors, functional studies were performed on $5-\mathrm{HT}_{2 \mathrm{~A}}$ and $5-\mathrm{HT}_{1 \mathrm{~B} / 1 \mathrm{D}}$ receptors in UCA from pre-eclamptic patients treated with KT. Methods: UCAs were obtained, immediately after delivery, from pre-eclamptic patients $(n=7)$, treated antenatally with intravenous KT. Pre-eclamptic patients $(n=13)$, not treated with KT (non-KT), were included as a control group. Segments of UCA were prepared and mounted in tissue baths and isometric force changes were determined. Cumulative concentration response curves to $5-\mathrm{HT}$ and to the $5-\mathrm{HT}_{1 \mathrm{~B} / 1 \mathrm{D}}$ receptor agonist sumatriptan were constructed in the absence or presence of
\end{abstract}

the $5-\mathrm{HT}_{2 \mathrm{~A}}$ receptor antagonist $\mathrm{KT}$ or the $5-\mathrm{HT}_{1 \mathrm{~B} / 1 \mathrm{D}}$ receptor antagonist GR125743, respectively. Results: All UCA segments showed contractile responses to both $5-\mathrm{HT}$ and sumatriptan, and the concentration response curves showed a rightward shift with increasing concentrations of KT and GR125743, respectively, indicating the presence of functional 5- $\mathrm{HT}_{2 \mathrm{~A}}$ and $5-\mathrm{HT}_{1 \mathrm{~B} / 1 \mathrm{D}}$ receptors in the foetal tissue. No significant differences were found in maximum response $\left(E_{\max }\right)$ (expressed in percent of response on $100 \mathrm{mM} \mathrm{KCl}$ ) or potency $\left(p E C_{50}\right)$ of $5-H T$ in both groups $\left(E_{\max }=141 \pm 7.7 \%\right.$, $\mathrm{pEC}_{50}=7.67 \pm 0.26$ in KT-treated group and $\mathrm{E}_{\max }=162 \pm$ $12.6 \%, \mathrm{pEC}_{50}=7.69 \pm 0.14$ in non-KT treated group, respectively). No significant differences were found in the potency of the antagonist $\mathrm{KT}$ in both study groups $\left(\mathrm{pK}_{\mathrm{b}}=7.65 \pm 0.31\right.$ in KT group and $7.46 \pm 0.17$ in non-KT group, respectively). Similarly, with sumatriptan, no significant differences were found between KT-treated patients and non-KT treated patients $\left(E_{\max }=142 \pm 16.2\right.$ and $140 \pm 14.7 \%$, respectively, $\mathrm{pEC}_{50}=6.17 \pm 0.37$ and $6.41 \pm 0.28$ respectively, $\mathrm{pK}_{\mathrm{b}}$ of GR125743 $=7.83 \pm 0.48$ and $8.43 \pm 0.29$, respectively). Conclusion: Foetal exposure to KT in pre-eclamptic patients does not seem to influence the functional characteristics of $5-\mathrm{HT}_{2 \mathrm{~A}}$ and $5-\mathrm{HT}_{1 \mathrm{~B} / 1 \mathrm{D}}$ receptors in the UCA.

Copyright $\odot 2007$ S. Karger AG, Basel

L.M. Hanff, PharmD, PhD

Department of Hospital Pharmacy, Erasmus MC Rotterdam

Dr. Molewaterplein 40

NL-3015 GD Rotterdam (The Netherlands)

Tel. +31 10463 3202, Fax +31 10436 6605, E-Mail l.hanff@erasmusmc.nl 


\section{Introduction}

Pre-eclampsia is a disease occurring in $2-5 \%$ of the pregnant women and it forms one of the leading causes of maternal and neonatal mortality and morbidity during pregnancy [1]. The pathophysiology of the disease is not yet fully understood, but impaired trophoblast invasion and endothelial dysfunction are considered to be important factors in the pathogenesis $[1,2]$. The main clinical characteristics of pre-eclamptic patients are elevated blood pressure, proteinuria and oedema, occurring after the twentieth week of gestation. Treatment with antihypertensive drugs is indicated to stabilize the patient and prevent maternal complications like organ failure or haemorrhages in retina or brain. Preterm delivery of, often severely growth-restricted, neonates occurs frequently in early-onset pre-eclamptic patients $[3,4]$.

In the past years, prolonging the pregnancy of earlyonset pre-eclamptic patients ('temporizing management'), using potent antihypertensive drugs, has been undertaken to improve neonatal outcome [5-7]. One of the antihypertensive drugs used most often in the Netherlands in the treatment of pre-eclampsia is the $5-\mathrm{HT}_{2 \mathrm{~A}}$ receptor antagonist ketanserin (KT). The drug is thought to act by blocking the vasoconstrictive response to 5 -HT in the blood vessels, while it is known to have some minor $\alpha_{1}$-receptor-blocking properties as well [8]. Its use in preeclampsia is based upon the assumption that an increased vasoconstrictive response to 5 -HT, leading to increased peripheral resistance, is one of the mechanisms involved in pre-eclampsia. Hence, the use of a 5-HT antagonist such as KT is considered a rational approach in the treatment of pre-eclampsia $[9,10]$. However, for temporizing management in severe, early-onset pre-eclamptic patients, high intravenous dosages of $\mathrm{KT}$ are needed for prolonged periods of time, resulting in extensive foetal exposure to KT. Indeed, concentrations of KT equal to maternal levels were found in the umbilical cord (26-373 $\mathrm{ng} / \mathrm{ml})$ and in the neonate $(71-302 \mathrm{ng} / \mathrm{ml})$ after maternal use of KT [11]. Whether these pharmacologically active concentrations of $\mathrm{KT}$, being a $5-\mathrm{HT}_{2 \mathrm{~A}}$ receptor antagonist, influence the characteristics and possibly cause desensitization of foetal 5-HT receptors, is unknown. In animal studies, chronic blockade of $5-\mathrm{HT}_{2 \mathrm{~A}}$ receptors by KT has been shown to lead to an unexpected down-regulation of $5-\mathrm{HT}_{2 \mathrm{~A}}$ receptors $[12,13] .5-\mathrm{HT}$ is known to be one of the earliest neurotransmitters produced during foetal brain development $[14,15]$. It can be speculated that foetal exposure to 5-HT receptor blocking drugs such as KT can cause harmful effects on the foetus, espe- cially considering the abundant presence of 5-HT receptors in the foetal brain. Although the currently available human studies have not yet shown clinical adverse effects in neonates clearly attributable to maternal KT treatment $[8,11,16]$, studying foetal 5 -HT receptors in functional studies will yield more detailed information regarding foetal development of these receptors and may lead to a better assessment of the risk of long-term effects in the neonate after maternal KT treatment. In our study, we selected the umbilical cord artery (UCA) as representative of foetal vessels and earlier studies demonstrate that $5-\mathrm{HT}_{2 \mathrm{~A}}$ and $5-\mathrm{HT}_{1 \mathrm{~B} / 1 \mathrm{D}}$ are the major receptors mediating 5-HT-induced vasoconstriction in human UCA [17].

Based on the results of animal studies [12, 13], we hypothesized that prolonged exposure of tissue and blood vessels to the $5-\mathrm{HT}_{2 \mathrm{~A}}$ receptor antagonist $\mathrm{KT}$ influences the functionality of foetal 5-HT receptors, by down-regulation of the $5-\mathrm{HT}_{2 \mathrm{~A}}$ receptor. The functionality of the $5-\mathrm{HT}_{1 \mathrm{~B} / \mathrm{D}}$ receptors was also studied, since it was speculated that the inhibiting effect of KT on platelet aggregation might reduce the release of 5-HT from platelets, which in turn may cause alterations in the density of the foetal $5-\mathrm{HT}_{1 \mathrm{~B} / 1 \mathrm{D}}$ receptor. Moreover, as mentioned earlier, beside $5-\mathrm{HT}_{2 \mathrm{~A}}$ receptors, $5-\mathrm{HT}_{1 \mathrm{~B} / 1 \mathrm{D}}$ is known to be the other type of receptors responsible for mediating the 5HT vasoconstriction response.

In the present study, functional responses of $5-\mathrm{HT}_{2 \mathrm{~A}}$ and $5-\mathrm{HT}_{1 \mathrm{~B} / 1 \mathrm{D}}$ receptors in UCA from pre-eclamptic patients treated with KT were compared with responses from pre-eclamptic patients not treated with KT.

\section{Methods}

Twenty pre-eclamptic patients admitted to the antenatal ward of the Erasmus MC were included in the study in the period 20022006. The ethics committee of the Erasmus MC approved the protocol and all patients gave informed consent prior to inclusion. Pre-eclampsia was defined as the occurrence, after 20 weeks of gestation, of a diastolic blood pressure $\geq 110 \mathrm{~mm} \mathrm{Hg}$ and a protein/creatinine ratio $\geq 30 \mathrm{mg} / \mathrm{mmol}$ creatinine or the occurrence of a repetitive diastolic blood pressure $\geq 90 \mathrm{~mm} \mathrm{Hg}$ in combination with the HELLP (haemolysis, elevated liver enzymes, low platelet count) syndrome.

The patients were divided into 2 study groups; 1 was treated with KT before delivery and the other with other antihypertensive drugs (dihydralazine, nifedipine or nicardipine) without exposure to KT. All patients in the non-KT group and the majority of patients $(86 \%)$ in the KT group used methyldopa orally.

$\mathrm{KT}$ treatment consisted of an intravenous bolus injection of 10 $\mathrm{mg}$ followed by a continuous infusion of KT at $4 \mathrm{mg} / \mathrm{h}$. According to the blood pressure, the infusion rate of KT was increased with $2 \mathrm{mg} / \mathrm{h}$ every $20 \mathrm{~min}$ to a maximum of $20 \mathrm{mg} / \mathrm{h}$. Each increment 
was preceded by an intravenous loading bolus injection of $10 \mathrm{mg}$ KT. Drug treatment was targeted at an intra-arterial diastolic blood pressure of $\leq 90 \mathrm{~mm} \mathrm{Hg}$. Antihypertensive treatment was continued as long as foetal and/or maternal condition did not warrant delivery, as judged by the attending obstetrician.

The umbilical cords were collected immediately after caesarean or vaginal deliveries.

Umbilical cord was collected in Krebs solution at $4^{\circ} \mathrm{C}$ (composition in mM: $\mathrm{NaCl} 118, \mathrm{KCl} 4.7, \mathrm{CaCl}_{2} 2.5, \mathrm{MgSO}_{4} 1.2, \mathrm{KH}_{2} \mathrm{PO}_{4}$ $1.2, \mathrm{NaHCO}_{3} 25$ and glucose 11.1, pH 7.4), transported to the laboratory and UCA was isolated from the umbilical cord. Functional experiments were performed on the same or subsequent day. Segments of UCA of 3-4 mm length and 1.5-2 mm internal diameter were suspended with the help of stainless steel hooks in 15-ml organ baths filled with carbogenated $\left(95 \% \mathrm{O}_{2}, 5 \% \mathrm{CO}_{2}\right) \mathrm{Krebs}$ solution at $37^{\circ} \mathrm{C}$. Each segment was set under a tension of $25 \mathrm{mN}$, as determined to be the optimal tension in pilot experiments.

The segments were washed after every $15 \mathrm{~min}$ and were allowed to equilibrate for $45 \mathrm{~min}$, to ensure that no maternal KT was present in the vessels before the start of the experiments. Two successive challenges to $\mathrm{KCl}(30 \mathrm{mM}$, Merck, Darmstadt, Germany) were performed to check the reproducibility of the response. $100 \mathrm{~mm} \mathrm{KCl}$ was subsequently added to determine the reference contractile response of the segment. Serotonin (5-HT, Sigma Chemicals Co., Steinheim, Germany) and sumatriptan (Pfizer Ltd., Sandwich, Kent, UK) were added to different segments in a cumulative manner in the absence or presence of antagonists. Concentration response curves to 5 - $\mathrm{HT}$ or to sumatriptan were constructed in a parallel set-up in the presence of vehicle or after 30 min of incubation with the $5-\mathrm{HT}_{2 \mathrm{~A}}$ antagonist $\mathrm{KT}(10 \mathrm{nM}, 100$ $\mathrm{nM}$ or $1 \mu \mathrm{M})$ (Pfizer) or the $5-\mathrm{HT}_{1 \mathrm{~B} / \mathrm{D}}$ antagonist GR125743 (10 nM, $100 \mathrm{nM}$ or $1 \mu \mathrm{M}$, Pfizer) [18], respectively. All agonists and antagonists were dissolved in distilled water and stored in aliquots at $-80^{\circ} \mathrm{C}$. Only a single concentration response curve was constructed in each artery segment.

\section{Data and Statistical Analysis}

Clinical characteristics between the 2 groups were compared using Wilcoxon's rank sum test. All contractile responses to the agonists were expressed as percentage contraction of the tone induced by $100 \mathrm{mM} \mathrm{KCl}$. All values were expressed as mean \pm SEM. The concentration response curves of the agonists were analyzed using non-linear regression analysis (Graph Pad Prism 3.01, Graph Pad Software Inc., San Diego, Calif., USA). The potency of agonist was expressed as $\mathrm{pEC}_{50}\left[-\log \left(\mathrm{EC}_{50}\right)\right]$. The apparent blocking potency of the antagonists (apparent $\mathrm{pK}_{\mathrm{b}}$ ) was estimated by calculating concentration ratios between $\mathrm{EC}_{50}$ values of agonist in the presence and in the absence of $100 \mathrm{nM}$ of the antagonists KT and GR125743 [19], assuming a slope of unity.

Statistical analysis was performed using SPSS (version 11.5, SPSS Inc., Chicago, Ill., USA).

Statistical significance was determined by the Student t test, with differences considered significant at $\mathrm{p}<0.05$. A post-hoc power analysis was performed to verify whether sufficient patients were investigated. Correlation coefficients between $\mathrm{pEC}_{50}$, $\mathrm{E}_{\max }$ or $\mathrm{pK}_{\mathrm{b}}$ and duration of $\mathrm{KT}$ treatment, cumulative dosage or maximum dosage was calculated according to Pearson's coefficient of correlation ( $\mathrm{r}$ ).

\section{Results}

The demographic and clinical characteristics of the 7 KT-treated and 13 non-KT-treated patients included in this study are summarized in table 1 . The groups did not differ significantly with respect to age, gestational age at admission or delivery, blood pressure at admission, neonatal weight or way of delivery. In all KT-treated patients, initially adequate blood pressure control was achieved with KT, but in 2 patients alternative intravenous antihypertensive drugs (nicardipine, $\mathrm{n}=1$; dihydralazine, $\mathrm{n}=$ 1) were added to maintain adequate blood pressure control. In 1 patient in the KT-treated group, KT treatment was stopped $2 \mathrm{~h}$ before delivery and in 1 patient $45 \mathrm{~h}$ before delivery. These patients were included in the analysis in the KT group because possible effects of maternal KT treatment on umbilical cord receptors were assumed to persist at least several days, considering the half-life of 5$\mathrm{HT}_{2}$ receptors of 3-5.5 days [20] and the elimination halflife of KT of 13-18 h [21].

The response to $100 \mathrm{mM} \mathrm{KCl}$ did not differ significantly between the study groups in the KT-treated group (36 $\pm 16 \mathrm{mN})$ versus the non-KT-treated group $(24 \pm 10$ $\mathrm{mN}) .5-\mathrm{HT}$ and the $5-\mathrm{HT}_{1 \mathrm{~B} / 1 \mathrm{D}}$ receptor agonist, sumatrip$\tan$, induced potent contractions in the UCA in both groups, which did not differ with respect to $\mathrm{E}_{\max }$ and $\mathrm{pEC}_{50}$ (fig. 1, table 2). The concentration response curves to 5HT showed a rightward shift after exposure to increasing concentrations of the $5-\mathrm{HT}_{2 \mathrm{~A}}$ antagonist KT (table 2, fig. 2a, b). In the rightward shifted curves after exposure to KT, slightly biphasic shaped curves may be seen (fig. 2a, b), which can be explained by the affinity of 5-HT to other 5-HT receptors, which are not antagonized by KT.

Similarly, 30 min incubation with the $5-\mathrm{HT}_{1 \mathrm{~B} / 1 \mathrm{D}}$ antagonist, GR125743, resulted in a rightward shift of the concentration response curves to sumatriptan (table 2). No statistical differences were found between the $\mathrm{pK}_{\mathrm{b}}$ values for the antagonists (KT or GR125743) of 5-HT receptors in UCA of pre-eclamptic patients treated with KT or those not treated with KT. Although our sample size was limited, a post-hoc power analysis $(\alpha=0.05, \beta=0.80)$ showed that the group size was sufficiently large to detect a difference in $\mathrm{pEC}_{50}$ of 0.7 , corresponding to a 5 -fold difference in potency, which we consider to be clinically relevant.

Data on duration of KT treatment, cumulative dosages and maximum dosages of the individual patients of the KT-treated group are shown in table 3. No correlations were found for 5-HT for $\mathrm{E}_{\max }$ or $\mathrm{pEC}_{50}$, with duration of $\mathrm{KT}$ treatment (for $\mathrm{E}_{\max }, \mathrm{r}=-0.539, \mathrm{p}=0.212$; for 
Table 1. Clinical characteristics of pre-eclamptic patients, treated with KT before delivery $(\mathrm{n}=7)$ or treated with other drugs (nifedipine, dihydralazine or nicardipine) before delivery $(\mathrm{n}=13)$

\begin{tabular}{lcc}
\hline & $\begin{array}{c}\text { Pre-eclamptic patients } \\
\text { treated with KT }\end{array}$ & $\begin{array}{c}\text { Pre-eclamptic patients not } \\
\text { treated with KT }\end{array}$ \\
\hline Age, years & $34[25-41]$ & $31[18-44]$ \\
BP diastolic at admission, mm Hg & $105\left[85^{1}-120\right]$ & $100[90-120]$ \\
BP systolic at admission, mm Hg & $180[140-220]$ & $160[110-200]$ \\
Protein/creatinine ratio, mg/mmol & $325[80-1,856]$ & $470[127-1,257]$ \\
Gestational age at admission, weeks & $28[254 / 7-35]$ & $294 / 7[244 / 7-346 / 7]$ \\
Gestational age at delivery, weeks & $31[264 / 7-362 / 7]$ & $306 / 7[263 / 7-366 / 7]$ \\
Way of delivery & & \\
Caesarian & $7(100)$ & $12(92)$ \\
Vaginal & 0 & $1(8)$ \\
Twin gestation & 0 & $1(8)$ \\
KT use & $54[17-399]$ & - \\
Duration of treatment, h & $9[6-18]$ & - \\
Maximum dosage, mg/h & $379[160-3,055]$ & - \\
Cumulative dosage, mg & & $13(100)$ \\
Other antihypertensive drugs & $6(86)$ & $3.5[1.5-4]$ \\
Methyldopa p.o. & $3[2-4]$ & $5(38)$ \\
Median dosage at delivery, g & $2(29)$ & $3(23)$ \\
Nifedipine p.o. & $1(14)$ & $3(23)$ \\
Dihydralazin i.v. & $4(57)$ & $1,205[650-2,165]$ \\
Nicardipin i.v. & $1,035[750-1,985]$ & $6(46)$ \\
Neonatal weight, g & $2(28)$ & $1(8)$ \\
Below 10th percentile & $1(14)$ & \\
Below 2.3th percentile & & \\
\hline
\end{tabular}
ses).

Data are expressed as medians (with ranges in square brackets) or numbers (with percentages in parenthe-

${ }^{1}$ One patient with severe HELLP syndrome.

Table 2. 5-HT receptor characteristics, expressed as mean ( $\pm \mathrm{SEM})$ of $\mathrm{E}_{\max }, \mathrm{pEC}_{50}$ and $\mathrm{pK}$ from UCA obtained from pre-eclamptic patients treated with $\mathrm{KT}$ and from pre-eclamptic patients not treated with $\mathrm{KT}$

\begin{tabular}{llllll}
\hline & \multicolumn{2}{l}{ Pre-eclamptic patients treated with KT } & & \multicolumn{2}{l}{ Pre-eclamptic patients not treated with KT } \\
\cline { 2 - 3 } & $5-\mathrm{HT}$ & sumatriptan & & $5-\mathrm{HT}$ & sumatriptan \\
\hline $\mathrm{E}_{\max }$ & $141 \pm 7.7(\mathrm{n}=7)$ & $142 \pm 16.2(\mathrm{n}=7)$ & & $162 \pm 12.6(\mathrm{n}=11)$ & $140 \pm 14.7(\mathrm{n}=11)$ \\
$\mathrm{pEC}_{50}$ & $7.67 \pm 0.26(\mathrm{n}=7)$ & $6.17 \pm 0.37(\mathrm{n}=7)$ & & $7.69 \pm 0.14(\mathrm{n}=11)$ & $6.41 \pm 0.28(\mathrm{n}=11)$ \\
$\mathrm{pK}_{\mathrm{b}}$ & $7.65 \pm 0.31(\mathrm{n}=5)$ & $7.83 \pm 0.48(\mathrm{n}=4)$ & & $7.46 \pm 0.17(\mathrm{n}=10)$ & $8.43 \pm 0.29(\mathrm{n}=8)$ \\
\hline
\end{tabular}

5-HT and sumatriptan were used as agonists in the absence or presence of KT (100 nM) and GR125743 $(100 \mathrm{nM})$ as their respective antagonists. $\mathrm{E}_{\text {max }}$ : expressed as percentage of the response induced by $100 \mathrm{mM}$ $\mathrm{KCl}$.

$\mathrm{pEC}_{50}, \mathrm{r}=-0.297, \mathrm{p}=0.518$ ), cumulative dosage (for $\mathrm{E}_{\max }$, $\mathrm{r}=-0.516, \mathrm{p}=0.236$; for $\left.\mathrm{pEC}_{50}, \mathrm{r}=-0.379, \mathrm{p}=0.401\right)$ and maximum dosage, respectively (for $\mathrm{E}_{\max }, \mathrm{r}=-0.024, \mathrm{p}=$ 0.959; for $\left.\mathrm{pEC}_{50}, \mathrm{r}=-0.333, \mathrm{p}=0.465\right)$. Similarly, no correlations were found for sumatriptan for $\mathrm{E}_{\max }$ or $\mathrm{pEC}_{50}$, with duration of KT treatment (for $\mathrm{E}_{\max }, \mathrm{r}=0.021, \mathrm{p}=$ 0.964; for $\mathrm{pEC}_{50}, \mathrm{r}=-0.058, \mathrm{p}=0.902$ ), cumulative dosage (for $\mathrm{E}_{\max }, \mathrm{r}=0.105, \mathrm{p}=0.822$; for $\mathrm{pEC}_{50}, \mathrm{r}=0.015$, $\mathrm{p}=0.974$ ) and maximum dosage, respectively (for $\mathrm{E}_{\max }$, $\mathrm{r}=0.524, \mathrm{p}=0.227$; for $\left.\mathrm{pEC}_{50}, \mathrm{r}=-0.272, \mathrm{p}=0.555\right)$. 

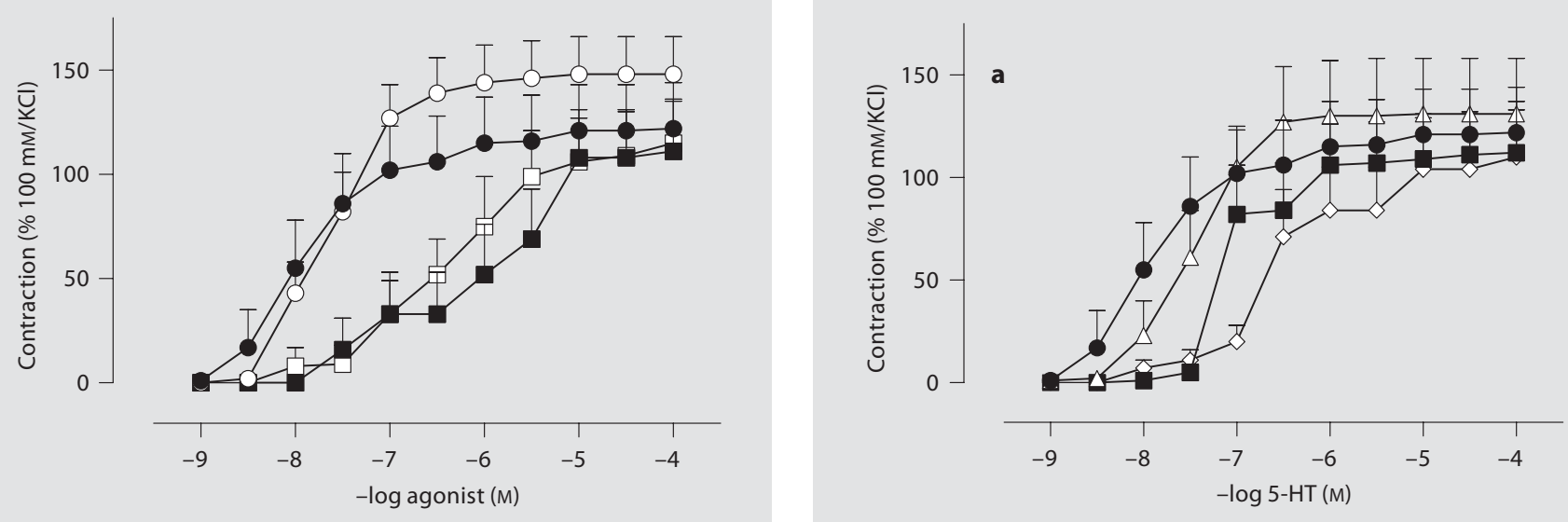

1

Fig. 1. Concentration response curves to $5-\mathrm{HT}$ in UCA segments of KT-treated patients $(\mathbf{n}, \mathrm{n}=7)$ and of patients not treated with $\mathrm{KT}(\mathrm{O}, \mathrm{n}=13)$ and concentration response curves to sumatriptan in UCA segments of KT-treated patients $(\boldsymbol{\square}, \mathrm{n}=7)$ and of patients not treated with $\mathrm{KT}(\square, \mathrm{n}=13)$.

Fig. 2. Concentration response curves to $5-\mathrm{HT}$ in the absence (O) or presence of increasing concentrations of the $5-\mathrm{HT}_{2 \mathrm{~A}}$ receptor antagonist, KT $[10 \mathrm{nM}(\triangle), 100 \mathrm{nM}(\boldsymbol{\square})$ and $1 \mu \mathrm{M}(\diamond)]$, in UCA segments of KT-treated patients $(n=7 ; \mathbf{a})$ and of patients not treated with $\mathrm{KT}(\mathrm{n}=13 ; \mathbf{b})$.

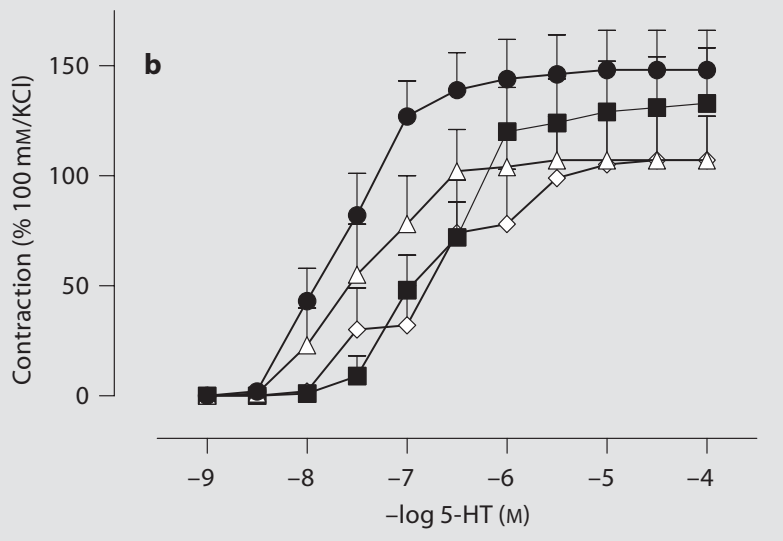

Table 3. Individual 5-HT receptor characteristics, expressed as $\mathrm{E}_{\max }$ and $\mathrm{pEC}_{50}$ from UCA obtained from preeclamptic patients treated with different dosages of KT

\begin{tabular}{|c|c|c|c|c|c|c|c|}
\hline \multirow[t]{2}{*}{ Patient } & \multirow{2}{*}{$\begin{array}{l}\text { Duration of } \\
\text { KT treatment } \\
\mathrm{h}\end{array}$} & \multirow{2}{*}{$\begin{array}{l}\text { Cumulative } \\
\text { dosage of KT } \\
\mathrm{mg}\end{array}$} & \multirow{2}{*}{$\begin{array}{l}\text { Maximum } \\
\text { dosage of KT } \\
\mathrm{mg} / \mathrm{h}\end{array}$} & \multicolumn{2}{|l|}{ 5-HT } & \multicolumn{2}{|c|}{ Sumatriptan } \\
\hline & & & & $\mathrm{E}_{\max }$ & $\mathrm{pEC}_{50}$ & $\mathrm{E}_{\max }$ & $\mathrm{pEC}_{50}$ \\
\hline 1 & 27 & 338 & 14 & 196 & 7.63 & 223 & 5.40 \\
\hline 2 & 110 & 379 & 9 & 142 & 8.74 & 111 & 5.42 \\
\hline 3 & 399 & 3,055 & 18 & 99 & 7.21 & 145 & 6.53 \\
\hline 4 & 121 & 850 & 10 & 164 & 6.63 & 173 & 5.12 \\
\hline 5 & 17 & 160 & 8 & 128 & 7.62 & 102 & 7.32 \\
\hline 6 & 54 & 414 & 8 & 127 & 8.24 & 115 & 5.80 \\
\hline 7 & 28 & 174 & 6 & 130 & 7.6 & 130 & 7.60 \\
\hline
\end{tabular}

5-HT and sumatriptan were used as agonists. $\mathrm{E}_{\max }$ : expressed as percentage of the response induced by 100 $\mathrm{mM} \mathrm{KCl}$. 


\section{Discussion}

The presence of $5-\mathrm{HT}_{2 \mathrm{~A}}$ and $5-\mathrm{HT}_{1 \mathrm{~B} / 1 \mathrm{D}}$ receptors in utero-placental vessels of normotensive patients has been described by several authors [22-24]. Increased concentrations of 5-HT have been reported at birth in maternal and placental circulation [25], indicating a role for 5-HT in maintaining vascular tone at birth. In pre-eclampsia, Middelkoop et al. [26] showed an increase in maternal circulation of 5-HT in pre-eclamptic patients, suggesting a role for 5-HT in the aetiology of pre-eclampsia.

In agreement with these studies, we found that 5-HT and sumatriptan induced contractions in all UCA tested, indicating the presence of $5-\mathrm{HT}$ receptors. KT and GR125743 shifted the 5-HT and sumatriptan curves rightwards in a concentration-dependent manner, confirming the presence of functional $5-\mathrm{HT}_{2 \mathrm{~A}}$ and $5-\mathrm{HT}_{1 \mathrm{~B} / 1 \mathrm{D}}$ receptors in UCA. The $\mathrm{pK}_{\mathrm{b}}$ values (7.65 and 7.46) of KT against $5-\mathrm{HT}$ are $1 \log$ unit lower than the $\mathrm{pA}_{2}$ values of 8.7-8.9 described by other authors for UCA [17, 27]. This might be explained by the fact that the blocking activity of $\mathrm{KT}$ is being underestimated in our experiments because 5-HT will have functional affinity for the $5-\mathrm{HT}_{1}$ receptor or other 5-HT subtypes [28] as well. Even though $5-\mathrm{HT}$ is not a selective $5-\mathrm{HT}_{2 \mathrm{~A}}$ receptor agonist, we chose 5 -HT as an agonist in this study as it encompasses the study of all 5-HT receptor subtypes and allows comparison of our results with other studies on 5-HT receptor functionality $[17,29,30]$. Furthermore, our results are in line with previously reported values of $\mathrm{pA}_{2}$ of 7.7-7.85 for $5-\mathrm{HT}_{2 \mathrm{~A}}$ receptor in animal tissue $[31,32]$.

The $\mathrm{pK}_{\mathrm{b}}$ value of GR125743 (7.83-8.43) for sumatrip$\tan$ is in accordance with previously observed $\mathrm{pA}_{2}$ values of 8.18 in human coronary artery and 8.34 in human saphenous vein [33].

The $5-\mathrm{HT}_{2 \mathrm{~A}}$ receptor antagonist $\mathrm{KT}$ has been increasingly used as an antihypertensive drug in pre-eclamptic patients in recent years. However, the substantial transplacental transmission and subsequently high foetal exposure to KT [11] may lead to adverse effects on foetal 5 -HT receptors. The early appearance and continued expression of foetal 5-HT receptors during gestation has been demonstrated in animal studies [15]. Lauder et al. [15] showed in mouse embryos that both structural as well as functional damage occurred after foetal exposure to high dosages of the $5-\mathrm{HT}_{2 \mathrm{~A} / 2 \mathrm{C}}$ receptor antagonist, mi-

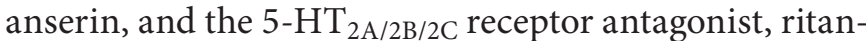
serin. No malformations were found after foetal exposure to KT. Whitaker et al. [34] demonstrated in animal studies that foetal exposure to the 5-HT receptor agonist, 5- methoxytryptamine, or exposure to a decreased level of maternal 5-HT (achieved by adding a tryptophan hydroxylase inhibitor antagonist) resulted in down-regulation and up-regulation of 5-HT receptors in newborn offspring, respectively.

In humans, only data on foetal effects after use of selective serotonin re-uptake inhibitors during pregnancy are available. These drugs have shown to affect foetal 5HT regulation, resulting in adverse effects on neonatal behaviour (tremor, restlessness, rigidity postnatally) following gestational exposure $[35,36]$. Based on the aforementioned data on adverse foetal effects after maternal drug use, we studied the effect of maternal KT treatment on foetal 5-HT receptor functional characteristics in preeclamptic patients. We hypothesized, based on animal studies $[12,13]$, that foetal exposure to KT might influence the functionality of $5-\mathrm{HT}_{2 \mathrm{~A}}$ receptor and eventually also the $5-\mathrm{HT}_{1 \mathrm{~B} / 1 \mathrm{D}}$ receptor.

Our data show no significant differences in 5-HT- or sumatriptan-induced vasoconstrictive responses of the UCA between the pre-eclamptic group treated with KT and the pre-eclamptic group without exposure to KT, indicating that exposure to KT does not influence foetal $5-\mathrm{HT}_{2 \mathrm{~A}}$ and $5-\mathrm{HT}_{1 \mathrm{~B} / 1 \mathrm{D}}$ receptor characteristics in UCA.

\section{Dosage and Duration of Treatment}

It can be expected that high dosages of $\mathrm{KT}$ and longterm treatment will exert a more pronounced effect on receptor characteristics than lower dosages, although all dosages used in this study were in the pharmacologically active range and have been known to cause high umbilical cord plasma levels of KT [11]. These plasma levels are in the same range as the concentrations of KT used in our in vitro experiments, indicating that results obtained with our experiments are of clinical relevance.

In our study no relationship between dosage and $\mathrm{pEC}_{50}$, $\mathrm{E}_{\max }$ or $\mathrm{pK}_{\mathrm{b}}$ could be established. It should be borne in mind that the number of patients in our study was relatively small, due to the fact that many early-onset preeclamptic patients need alternative treatment before delivery after the maximum dosage of $\mathrm{KT}$ is reached. However, power analysis established that the statistical power in our study was sufficient to detect a 5-fold difference in potency, which we consider clinically relevant.

\section{Gestational Age}

Limited information is available with respect to the influence of gestational age on the response of the umbilical artery to 5-HT. Bertrand and St-Louis [29] showed an increase in umbilical and placental vein sensitivity to 
serotonin throughout the third trimester in normotensive patients, whereas this change was not seen in preeclampsia. We also showed that with advancing gestational age, an increase in the sensitivity of $5-\mathrm{HT}_{1 \mathrm{~B} / 1 \mathrm{D}}$ receptors in UCA in normotensive patients can be found [37]. In our study the groups did not differ with respect to gestational age, therefore a possible confounding factor of gestational age on the results was excluded. However, it can be speculated that clinical effects of maternal KT treatment on the receptor population will (partly) depend on gestational age, if sensitivity to 5-HT in UCA indeed changes with gestational age.

Our results, suggesting a lack of effect of maternal KT treatment on the functionality of 5-HT receptors in UCA, support the currently available clinical data, showing that use of KT in pre-eclamptic patients is safe for foetus and neonate.

In conclusion, prolonged foetal exposure to KT in preeclamptic patients does not seem to influence the functional characteristics of $5-\mathrm{HT}_{2 \mathrm{~A}}$ and $5-\mathrm{HT}_{1 \mathrm{~B} / 1 \mathrm{D}}$ receptors in the UCA.

\section{Acknowledgements}

The authors thank the students M. Schippers, D. Misiunienie, S. Kalo and M. Helmond for their assistance with the experiments.

\section{References}

1 Sibai B, Dekker G, Kupfermine M: Pre-eclampsia. Lancet 2005;365:785-799.

-2 Roberts JM, Lain KY: Recent insights into the pathogenesis of pre-eclampsia. Placenta 2002;23:359-372.

-3 Hauth JC, Ewell MG, Levine RL, Esterlitz JR, Sibai BM, Curet LB: Pregnancy outcomes in healthy nulliparas women who subsequently developed hypertension. Obstet Gynecol 2000;85:24-28.

4 Paruk F, Moodley J: Maternal and neonatal outcome in early- and late-onset pre-eclampsia. Semin Neonatol 2000;5:197-207.

$\checkmark 5$ Visser W, Wallenburg HCS: Maternal and perinatal outcome of temporising management in 254 consecutive patients with severe preeclampsia remote from term. Eur J Obstet Gynecol Reprod Biol 1995;63:147-154.

6 Schiff E, Friedman SA, Sibai BM: Conservative management of severe preeclampsia remote from term. Obstet Gynecol 1994;84: 626-630

-7 Sibai B, Mercer BM, Schiff E, Friedman SA: Aggressive versus expectant management of severe preeclampsia at 28 to 32 weeks' gestation: a randomized controlled trial. Am J Obstet Gynecol 1994;171:818-822.

-8 Bolte AC, van Geijn HP, Dekker GA: Pharmacological treatment of severe hypertension in pregnancy and the role of serotonin(2)-receptor blockers. Eur J Obstet Gynecol Reprod Biol 2001;95:22-36.

-9 Bolte AC, van Geijn HP, Dekker GA: Pathophysiology of preeclampsia and the role of serotonin. Eur J Obstet Gynecol Reprod Biol 2001;95:12-21.

10 Hutter C, Crighton IM, Smith K, Liu DTY: The role of serotonin in preeclamptic hypertension. Int J Obstet Anesth 1996;5:108114.
11 HanffLM, VisserW, RoofthooftDW, Bulsink MJ, Vermes A, Steegers EA, Vulto AG: Ketanserin in pre-eclamptic patients: transplacental transmission and disposition in neonates. BJOG 2004;111:863-866.

12 Pranzatelli MR: Regulation of 5HT2 receptors in rat cortex; studies with a putative selective agonist and an antagonist. Biochem Pharmacol 1991;42:1099-1105.

-13 Gandolfi O, Barbaccia ML, Costa E: Different effects of serotonin antagonists on $3 \mathrm{H}$ mianserin and $3 \mathrm{H}$-ketanserin recognition sites. Life Sci 1985;36:713-721.

14 Wallace JA, Lauder J: Development of the serotonergic system in the rat embryo; an immunochemical study. Brain Res Bull 1983; 10:459-479.

15 Lauder JM, Wilkie MB, Wu C, Singh S: Expression of 5-HT2a, 5-HT2b and 5-HT2c receptors in the mouse embryo. Int J Dev Neurosci 2000;18:653-662.

16 Steyn DW, Odendaal HJ, Kirsten GF: Mental development in children six years after in utero exposure to ketanserin - a follow-up study of a randomized controlled trial. Hypertens Pregnancy 2002;21(suppl 1):131.

$\checkmark 17$ Lovren F, Li X, Lytton J, Triggle C: Functional characterisation and m-RNA expression of 5-HT receptors mediating contraction in human umbilical artery. Br J Pharmacol 1999;127:1247-1255.

18 Domenech T, Beleta J, Palacios JM: Characterization of human serotonin $1 \mathrm{D}$ and $1 \mathrm{~B}$ receptors using $\left[{ }^{3} \mathrm{H}\right]-\mathrm{GR}-125743$, a novel radiolabelled serotonin $5 \mathrm{HT}_{1 \mathrm{D} / 1 \mathrm{~B}}$ receptor antagonist. Naunyn Schmiedebergs Arch Pharmacol 1997;356:328-334.

19 Arunlakshana O, Schild HO: Some quantitative uses of drug antagonists. Br J Pharmacol 1959;14:48-58.
20 Leysen JE, Janssen PFM, Niemegeers CJE: Rapid densitization and down-regulation of 5HT2 receptors by DOM treatment. Eur J Pharmacol 1989;163:145-149.

- 21 Heykants J, van Peer A, Woestenborghs R, Gould S, Mills J: Pharmacokinetics of ketanserin and its metabolite ketanserin-ol in man after intravenous, intramuscular and oral administration. Eur J Clin Pharmacol 1986; 31:343-350.

22 Karlsson C, Bodelsson G, Bodelsson M, Stjernquist M: Characterisation of 5-hydroxytryptamine receptors mediating circulating smooth muscle contraction in the human umbilical artery. Gynecol Obstet Invest 1999;47:102-107.

23 Cruz MA, Gallardo V, Miguel P, Carrasco G, Gonzales C: Mediation by 5-HT2 receptors of 5-hydroxytryptamine-induced contractions of human placental vein. Gen Pharmacol 1998;30:483-488.

24 Huang WQ, Zhang CL, Di XY, Zhang RQ: Studies on the localisation of 5-hydroxytryptamine and its receptors in human placenta. Placenta 1998;19:655-661.

25 Jones JB, Rowsell A: Foetal 5-hydroxytryptamine levels in late pregnancy. J Obstet Gynaecol 1973;80:687-689.

26 Middelkoop CM, Dekker GA, Kraayenbrink AA, Popp-Snijders C: Platelet-poor plasma serotonin in normal and preeclamptic pregnancy. Clin Chem 1993;39:1675-1678.

27 MacLennan SJ, Whittle MJ, McGrath JC: 5 - $\mathrm{HT}_{1}$-like receptors requiring functional cyclo-oxygenase and 5- $\mathrm{HT}_{2}$ receptors independent of cyclo-oxygenase mediate contraction of the human umbilical artery. Br J Pharmacol 1989;97:921-933.

28 Tuncer M, et al: Receptor mechanism for 5hydroxytryptamine in isolated human umbilical artery and vein. Arch Int Pharmacodyn Ther 1985;276:17-27. 
-29 Bertrand C, St-Louis J: Reactivities to serotonin and histamine in umbilical and placental vessels during the third trimester after normotensive pregnancies and pregnancies complicated by pre-eclampsia. Am J Obstet Gynecol 1999;180:650-659.

-30 Cocks TM, Kemp BK, Pruneau D, Angus JA: Comparison of contractile responses to 5 -hydroxytryptamine and sumatriptan in human isolated coronary artery: synergy with the thromboxane A2-receptor agonist, U46619. Br J Pharmacol 1993;110:360-368.

\31 Siriwardena A, Kellum JM: A 5-HT2 receptor mediates serotonin-induced electrolyte transport in rat left colon. J Surg Res 1993;55: 323-329.
32 Yildiz O, Tuncer M: Characterization of 5 hydroxytryptamine receptors in rabbit isolated iliac artery. Arch Int Pharmacodyn Ther 1993;326:72-83.

33 Van den Broek RWM, MaassenvandenBrink A, de Vries R, Bogers AJJC, Stegmann APA Avezaat CJJ, Saxena PR: Pharmacological analysis of contractile effects of eletriptan and sumatriptan on human isolated blood vessels. Eur J Pharmacol 2000;407:165-173.

34 Whitaker-Azmitia PM, Lauder JM, Shemmer A, Azmititia EC: Postnatal changes in serotonin1 receptors following prenatal alteration in serotonin levels; further evidence for functional foetal serotonin1 receptors. Dev Brain Res 1987;33:285-289.
35 Laine K, Heikkkinen T, Ekblad U, Kero P: Effects on exposure to selective serotonin reuptake inhibitors during pregnancy on serotonergic symptoms in newborns and cord blood monoamine and prolactin concentrations. Arch Gen Psychiatry 2003;60:720-726.

36 Zeskind PS, Stephens LE: Maternal selective serotonin reuptake inhibitor use during pregnancy and newborn behavior. Pediatrics 2004;113:368-375.

37 Gupta S, Hanff LM, Visser W, Steegers EA, Saxena PR, Vulto AG, MaassenvandenBrink A: Functional reactivity of 5-HT receptors in human umbilical cord and maternal subcutaneous fat arteries after normotensive or pre-eclamptic pregnancy. J Hypertens 2006; 24;1345-1353. 